\title{
Um livro que enriquece as referências em Jornalismo Literário
}

DOI: 10.1590/1809-58442017315

\section{Eduardo Ritter}

(Universidade Federal de Santa Maria, Departamento de Comunicação, Curso de Comunicação Social - Habilitação em Jornalismo. Santa Maria - RS, Brasil)

MONICA, Martinez. Jornalismo literário: tradição e inovação. Florianópolis: Insular, 2016. 452p.

O livro “Jornalismo literário: tradição e inovação” é a síntese de 25 anos dedicados pela autora, Monica Martinez, ao tema Jornalismo Literário (JL). A obra, que integra a Série Jornalismo a Rigor, da editora Insular, revisita, reflete e inova os pensamentos sobre o assunto. A coletânea de artigos produzidos ao longo do referido período, revistos e ampliados por Martinez, são divididos em quatro grandes temáticas: 1) História, conceito e filosofia; 2) Potencialidades do gênero; 3) A presença nas mídias; e 4) Experimentações e possíveis inovações.

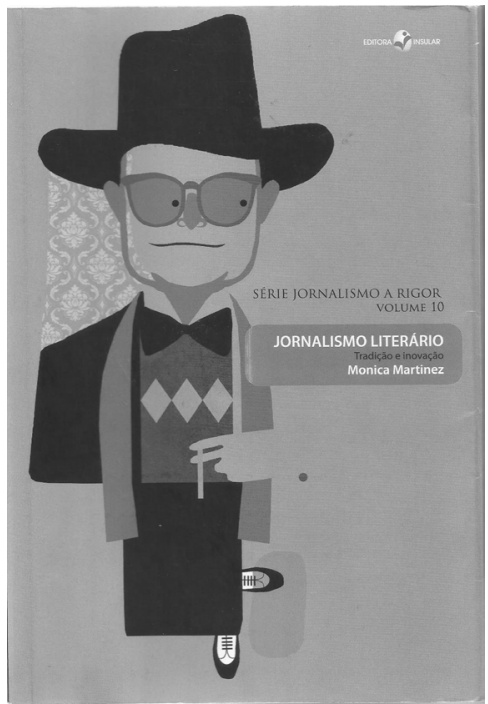

Nos dois textos que aparecem na primeira parte, a autora recupera perspectivas de diversos autores consagrados, tanto na produção, quanto nas teorizações sobre JL: de João do Rio e José Hamilton Ribeiro à Gay Talese e Truman Capote, de Mark Kramer ao professor Edvaldo Pereira Lima, autor de grande influência sobre Martinez.

Já quando a autora trata sobre as potencialidades do gênero, são apresentados seis capítulos. No primeiro, é apresentado um estudo quantitativo e analítico sobre a produção de obras de JL publicadas pela editora Companhia das Letras, que lançou 33 títulos do gênero até 2016. Ela também faz esse levantamento e análise em relação às publicações na produção científica da Sociedade Brasileira de Estudos Interdisciplinares da Comunicação (Intercom).

Um dos capítulos que merece destaque na obra é intitulado Relatos do trânsito humano, abordando narrativas de viagem no JL. Nesse capítulo, ela apresenta a história e a conceituação desse tipo de narrativa, retomando não só os textos que resultaram em livros-reportagem, mas também de revistas e jornais que ficaram conhecidos por publicar narrativas de viagem de qualidade, tais como a americana The New Yorker e a National Geographic Magazine. 
Na sequência, a autora aborda as narrativas biográficas, apresentando desde a etimologia do termo "biografia”, destacando o estado da arte do objeto e, posteriormente, apresentando uma classificação para esse tipo de jornalismo literário, a saber: 1) Perfil: narrativa biográfica curta presentificada; 2) Memória; 3) Biografia; 4) Ensaio pessoal; e 5) Narrativa de viagem. Outro ponto a destacar é que, ao longo de toda a obra, os temas e capítulos podem ser relacionados um com os outros, independentemente de qualquer sequência.

Finalizando essa etapa, Martinez apresenta três textos aprofundando as produções de JL relacionadas com a temática morte. No primeiro, são trabalhados os obituários do jornal Folha de S. Paulo. Posteriormente, a autora segue com a temática, mas agora trabalhando o estilo de dois autores do mesmo jornal paulista: Willian Vieira e Estevão Bertoni. Assim como nesse capítulo, bem como em outros, são apresentadas as mais diversas reflexões, todas bem embasadas e bem articuladas, sobre temáticas relacionadas ao JL, tais como no subcapítulo A fronteira tênue entre literatura e jornalismo. Por fim, Martinez analisa relatos de morte num comparativo entre Brasil e Estados Unidos, tendo como objeto de estudo os obituários da Folha de S. Paulo e do The New York Times. Para tanto, é feita uma completa contextualização histórica das experiências estadunidense e brasileira.

A parte intitulada A presença nas mídias é a mais ampla da obra, contendo sete capítulos. Essa também é uma das partes mais inovadoras, pois começa com uma revisita à obra do jornalista Joseph Mitchell, salientando a excelente habilidade que ele apresentava para escutar histórias a fim de construir suas narrativas. "Em jornalismo impresso, um dos maiores exemplos de profissional que empregou a escuta como ferramenta de produção textual é o estadunidense Joseph Mitchell (1908-1996)” (p.178).

Em um segundo momento, Martinez apresenta dois capítulos sobre jornalismo literário e mídia sonora. No primeiro, ela exibe e analisa 52 edições do programa chamado Conte sua história de São Paulo, veiculado pela Rádio CBN em 2009. Para tanto, a autora expõe como aparecem as características do JL nesses programas, tais como apuração, digestão e compreensão do material apurado, e redação em estilo literário. No capítulo sequente, Martinez faz um comparativo do caso brasileiro do Conte a sua história de São Paulo com o National History Project, idealizado pelo escritor Paul Auster, nos Estados Unidos, e veiculado uma vez por mês no programa All Things Considered, da National Public Radio.

Já para abordar o JL em mídias eletrônicas, mais especificamente na televisão, a autora define como objeto o programa Globo Rural, tendo participação destacada de um escritor-jornalista consagrado: José Hamilton Ribeiro. Novamente a autora percorre as definições e funções do JL, tais como imersão, compreensão, universalização temática, estilo próprio e voz autoral, dentre outras. No capítulo sequente, Martinez aprofunda a temática, observando e analisando o trabalho do jornalista Nelson Araújo dentro do programa Globo Rural. Ainda relacionando o jornalismo literário com o audiovisual, em outro texto, 
a autora faz ótimas reflexões sobre as relações com o cinema e o documentário, destacando, por exemplo, a linguagem cinematográfica, a captação de informações, a montagem de imagens e a estrutura do texto. Já para falar sobre mídias digitais, é analisada a produção da jornalista e escritora Eliane Brum para o portal da Revista Época.

Por fim, na última parte do livro, Martinez apresenta uma retomada na questão da importância do diálogo e da escuta atenta no JL para, posteriormente, abordar as narrativas jornalísticas curtas tendo como objeto a produção de haicais. Já os dois últimos capítulos relacionam o jornalismo literário com: 1) heróis e heroínas em tempos digitais e 2) o método da biografia humana e pessoas com mais de 60 anos. Como posfácio, a professora da Universidade de Sorocaba ainda brinda o leitor com algumas reflexões pessoais sobre JL e apresenta um pequeno guia comentado de livros sobre a temática.

Diante de uma obra de tanto fôlego, conclui-se que Jornalismo Literário, de Monica Martinez, não só passa a ser um livro obrigatório na estante de qualquer apaixonado pela temática, bem como a autora, após quase três décadas dedicadas ao tema, já se tornou uma das principais referências sobre JL, ao lado de outros autores brasileiros consagrados, tais como Edvaldo Pereira Lima, Antonio Hohlfeldt, Felipe Pena, Marcelo Bulhões, Juremir Machado da Silva, dentre outros.

\section{Eduardo Ritter}

Graduado em Comunicação Social - Jornalismo pela Universidade Regional do Noroeste Social do Rio Grande do Sul (Unijuí), mestre e doutor em Comunicação Social pela Pontifícia Universidade Católica do Rio Grande do Sul (PUCRS), com período sanduíche na New York University (Estados Unidos). Professor Adjunto do Departamento de Comunicação da Universidade Federal de Santa Maria (UFSM), campus Frederico Westphalen. E-mail: rittergaucho@hotmail.com.

Recebido em: 30.12.2016

Aceito em: 09.06.2017 